\title{
Purinergic signaling in the lumen of a normal nephron and in remodeled PKD encapsulated cysts
}

\author{
Michael B. Hovater • Dragos Olteanu • \\ Elisabeth A. Welty • Erik M. Schwiebert
}

Received: 17 December 2007 / Accepted: 8 April 2008/Published online: 26 April 2008

(C) Springer Science + Business Media B.V. 2008

\begin{abstract}
The nephron is the functional unit of the kidney. Blood and plasma are continually filtered within the glomeruli that begin each nephron. Adenosine 5' triphosphate (ATP) and its metabolites are freely filtered by each glomerulus and enter the lumen of each nephron beginning at the proximal convoluted tubule (PCT). Flow rate, osmolality, and other mechanical or chemical stimuli for ATP secretion are present in each nephron segment. These ATP-release stimuli are also different in each nephron segment due to water or salt permeability or impermeability along different luminal membranes of the cells that line each nephron segment. Each of the above stimuli can trigger additional ATP release into the lumen of a nephron segment. Each nephron-lining epithelial cell is a potential source of secreted ATP. Together with filtered ATP and its metabolites derived from the glomerulus, secreted ATP and adenosine
\end{abstract}

M. B. Hovater · D. Olteanu $\cdot$ E. A. Welty $\cdot$ E. M. Schwiebert $(\bowtie)$

Department of Physiology and Biophysics,

University of Alabama at Birmingham,

MCLM 740, 1918 University Blvd.,

Birmingham, AL 35294-0005, USA

e-mail: issytman@uab.edu

\section{E. M. Schwiebert}

Department of Cell Biology,

University of Alabama at Birmingham,

MCLM 740, 1918 University Blvd.,

Birmingham, AL 35294-0005, USA

E. M. Schwiebert

Recessive PKD Translational and Research Core Centers,

University of Alabama at Birmingham,

Birmingham, AL, USA

E. M. Schwiebert

Comprehensive Kidney Disease Research Center,

University of Alabama at Birmingham,

Birmingham, AL, USA derived from cells along the nephron are likely the principal two of several nucleotide and nucleoside candidates for renal autocrine and paracrine ligands within the tubular fluid of the nephron. This minireview discusses the first principles of purinergic signaling as they relate to the nephron and the urinary bladder. The review discusses how the lumen of a renal tubule presents an ideal purinergic signaling microenvironment. The review also illustrates how remodeled and encapsulated cysts in autosomal dominant polycystic kidney disease (ADPKD) and remodeled pseudocysts in autosomal recessive PKD (ARPKD) of the renal collecting duct likely create an even more ideal microenvironment for purinergic signaling. Once trapped in these closed microenvironments, purinergic signaling becomes chronic and likely plays a significant epigenetic and detrimental role in the secondary progression of PKD, once the remodeling of the renal tissue has begun. In PKD cystic microenvironments, we argue that normal purinergic signaling within the lumen of the nephron provides detrimental acceleration of ADPKD once remodeling is complete.

Keywords Signaling - ATP - Adenosine - Nucleotides · Nucleosides $\cdot$ Kidney $\cdot$ Polycystic kidney disease

Abbreviations
PCT
ATP
ADP
UTP
UDP
Ado
RBF
GFR
ARPKD

proximal convoluted tubule adenosine $5^{\prime}$ triphosphate adenosine $5^{\prime}$ diphosphate uridine $5^{\prime}$ triphosphate uridine $5^{\prime}$ diphosphate adenosine renal blood flow glomerular filtration rate autosomal recessive polycystic kidney disease 


$\begin{array}{ll}\text { ADPKD } & \begin{array}{l}\text { autosomal dominant polycystic kidney } \\ \text { disease }\end{array} \\ \text { P2 receptors } & \begin{array}{l}\text { ATP-sensing P2Y G protein-coupled } \\ \text { receptors and ATP-gated P2X receptor } \\ \text { channels }\end{array} \\ & \text { A1, A2a, A2b, and A3 adenosine- } \\ \text { P1 receptors } & \text { sensing G protein-coupled receptors } \\ & \text { ATP-binding cassette transporters } \\ \text { ABC transporters } & \text { multiple organic anion transporters } \\ \text { MOATs } & \text { P-glycoprotein } \\ \text { PGP } & \text { multidrug resistance transporter } \\ \text { mdr } & \text { para-amino hippurate } \\ \text { PAH } & \text { cortical thick-ascending limb } \\ \text { cTAL } & \text { medullary thick-ascending limb } \\ \text { mTAL } & \text { thick ascending limb } \\ \text { TAL } & \text { macula densa } \\ \text { MD } & \text { juxtaglomerular apparatus } \\ \text { JGA } & \text { distal convoluted tubule } \\ \text { DCT } & \text { tubuloglomerular feedback } \\ \text { TG feedback } & \text { calcium } \\ \text { Ca }{ }^{2+} & \text { phospholipase C } \\ \text { PLC } & \text { protein kinase C } \\ \text { PKC } & \text { epithelial Na+ channel } \\ \text { ENaC } & \text { water } \\ \mathrm{H}_{2} \mathrm{O} & \text { adterstitial cystitis } \\ \text { IC } & \\ 5 ' \text { AMP } & \\ & \end{array}$

\section{Introduction: sites and modes of adenosine 5 ' triphosphate secretion and its regulation along the nephron}

Glomerulus A classical example of an autocrine or paracrine signaling microenvironment is the renal nephron. A diagram of the classic nephron is provided in Fig. 1. Within the glomerular capillaries, red and white blood cells alike are squeezed through these small capillaries and deformed in the process. Sprague and coworkers studied deformationinduced adenosine $5^{\prime}$ triphosphate (ATP) release in erythrocytes for many years, as have others [1-3]. With regard to mechanically released ATP, ATP and their metabolites are present in plasma at finite amounts, and the amount of nucleotides and nucleosides freely filtered at the glomerulus is likely to be low to negligible. However, deformation of blood cells may provide more ATP to be filtered than is appreciated. More likely, however, nucleotides are secreted under basal conditions and in response to a variety of mechanical, osmotic, and chemical stimuli by most - if not all - cells of the glomerulus and its associated vasculature, as well as the proximal tubule cells rich in mitochondria [46]. Ecto-ATPases and ectoadenosine 5' diphosphatases (ADPases) are also present throughout the nephron [712], although their nephron-specific localization has not been studied in depth. Their action generates metabolites that are also active at $\mathrm{P} 2$ receptors $\left[\mathrm{ADP}\right.$ and uridine $5^{\prime}$ diphosphate (UDP)] [13-15]. Ecto-5'-nucleotidases are also present at discrete points along the nephron [16-18]. Nucleotidases have been mapped more precisely along the nephron, and their enzymatic action generates the wellknown active purinergic metabolite adenosine (Ado), which binds to and activates P1 receptors [19-21].

Proximal tubule Each purinergic ligand (as pictured in Fig. 1) can appear or be generated within the lumen of a renal proximal tubule where it becomes trapped within the lumen of each single nephron. These ligands can signal at luminal receptors in the proximal tubule or be carried to downstream nephron segments by the tubular fluid. The proximal tubule segments may be a rich and additional source of secreted ATP for multiple reasons. Despite an isosmotic environment, flow rate is high through this initial nephron segment due to renal blood flow (RBF) physical forces that drive a robust glomerular filtration rate (GFR). These forces dissipate as the tubular fluid traverses the loop of Henle. Hence, flow and/or shear stress may be robust stimuli for ATP secretion in the convoluted and straight tubules. Other ATP-release mechanisms in proximal tubule have been postulated and are presented below.

Proximal-tubule-based large anion secretion Drug secretion and organic acid secretion also occur in the proximal tubule [22-25]. The classic example is para-amino hippurate (PAH), which is often used as a marker for PCT secretion [4-6]. It is well known that the proximal tubule is enriched in the expression of ATP-binding cassette (ABC) transporters [22-25]. In particular, the multiple organic anion transporters (MOATs) are expressed in abundance [22-25]. Their principal function is the secretion of large organic anions [22-25], of which ATP is a principal one. Upon chronic administration of a significant dose of one or more drugs in a human patient with a disease condition, the multidrug resistance (mdr) transporters [known as $\mathrm{P}$ glycoprotein (PGP), etc.] will be upregulated and may also be a robust transporter conduit for ATP and other large anions [22-25]. This minireview does not revisit the debate concerning the role of ABC transporters in ATP transport and release; however, past reviews of this biology are cited here for interested parties [13-15, 26, 27].

Loop of Henle: focus on the cortical thick-ascending limb (cTAL) The loop of Henle and its role in nephron intraluminal purinergic signaling is less clear. It may act as a conduit for ATP filtered at the glomerulus and secreted by the proximal tubule in order to present a set (ATP) to the macula densa. Higher flows of tubular fluid than normal could trigger additional ATP secretion along the loop of 


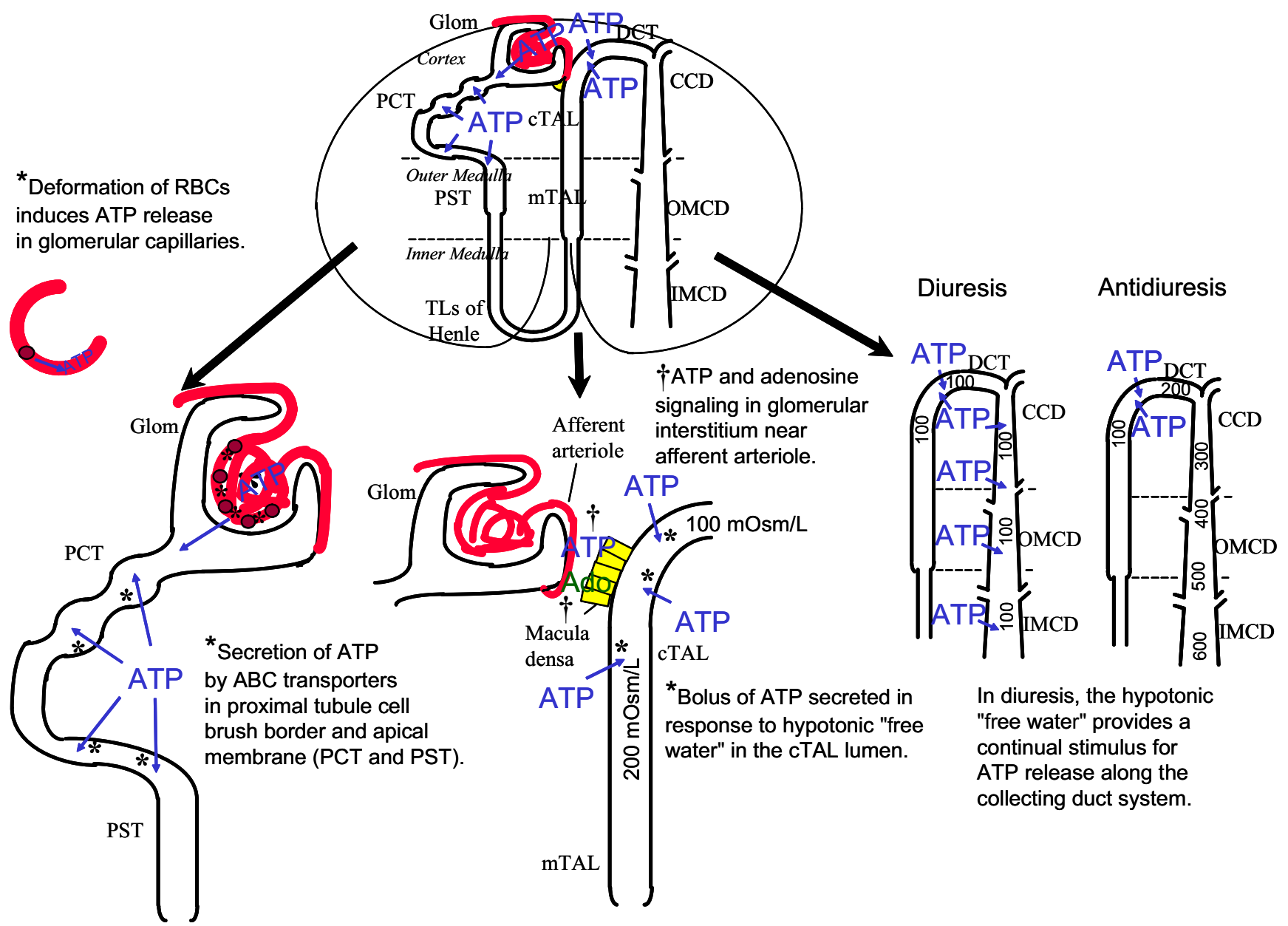

Fig. 1 Nucleotide secretion along the nephron: current postulates. Although not pictured as such, the sources of secreted ATP along the nephron are the renal epithelial cells themselves that line each nephron segment

Henle. Importantly, as water accumulates due to the impermeability of the thick-ascending limb of the loop of Henle, this tubular fluid becomes hypotonic with respect to the interstitium and plasma. As a consequence, ATP secretion is triggered by hypotonic cell swelling, which can also be thought of as an osmotic and mechanical stimulus. Therefore, the existence of the free water in the cTAL at the level of the macula densa or juxtaglomerular apparatus (JGA), a tubular fluid normally $100 \mathrm{mOsm} / \mathrm{kg}$ $\mathrm{H}_{2} \mathrm{O}$ or $100 \mathrm{mOsm} / 1$ [4-6], begs a question. Is there routinely a robust stimulus for ATP secretion at this point in every nephron? If so, a bolus of ATP secretion is likely routinely released at the level of the cTAL and distal convoluted tubule (DCT) to affect collecting duct physiology. Could proximal tubule (ATP) or that of its metabolite (adenosine) be sensed at the level of the JGA? Flow, salt, and osmolality have been postulated as factors sensed by the specialized cells of the macula densa. However, an autocoid that is normally secreted at a certain rate and in a certain amount due to a normal GFR may be hypersecreted when RBF and GFR are high and hyposecreted when GFR is low. This postulate is plausible and is still being actively pursued. It is also important to state that other autocoids may serve this role in tubuloglomerular feedback.

Macula densa, cTAL, and tubuloglomerular (TG) feedback A routine bolus of secreted ATP at the level of the macula densa agrees with the work of several laboratories examining the role of purinergic signaling in tubuloglomerular (TG) feedback between the macula densa and nearby afferent arterioles of the glomerulus. Significant roles for both nucleotides (ATP) and nucleosides (Ado) have been proposed. From our assessment of the literature, both families of purinergic ligands are likely involved at multiple levels in TG feedback. The interstitium composed of mesangial cells and extracellular matrix interconnected with the patch of specialized macula densa cells of the cTAL and the afferent arterioles nearby is another ideal microenvironment for purinergic signaling. These paradigms have been reviewed and discussed by several prominent investigators, including, but not limited to, Bell, Inscho, Schnermann, Garvin, Osswald, and others 
$[8,28-40]$. Seminal diagrams in their reviews illustrate their findings [28-39].

Briefly, Peti-Peterdi and coworkers [31, 35], and Inscho and colleagues have championed a hypothesis that ATP release occurs upon the macula densa sensing changes in salt load and/or flow. The authors, together with Okada and coworkers, showed that a voltage-dependent anion channel (VDAC) or porin-like maxi anion channel was a likely candidate to facilitate ATP secretion by the macula densa cell [31, 40]. Secreted ATP then binds to P2X receptor channels (likely $\mathrm{P} 2 \mathrm{X}_{1}$ according to Inscho and colleagues [30]) on the afferent arteriole, causing it to vasoconstrict and creating decreased RBF and GFR. In elegant imaging using two-photon technology, Peti-Peterdi [40] and Komlosi et al. [31] showed the macula densa cells swell in response to a hypotonic cTAL tubular fluid-like perfusate and the corresponding afferent arteriole constrict in the individually dissected glomerulus and cTAL-coupled tissue preparation. In elegant subsequent work, Peti-Peterdi, in his own laboratory [35], found that a calcium $\left(\mathrm{Ca}^{2+}\right)$ wave is triggered by increased flow rate of cTAL perfusate that was propagated from the macula densa to both extraglomerular mesangial cells and juxtaglomerular renin granular cells. This flow-induced $\mathrm{Ca}^{2+}$ wave was also propagated to distant glomerular podocytes. Uncoupling of gap junctional connexin channels and scavenging of extracellular ATP and ADP by apyrase and hexokinase abolished the change in $\mathrm{Ca}^{2+}$ at the macula densa and/or the propagation of the $\mathrm{Ca}^{2+}$ wave. Garvin and coworkers also argued for prominent roles of cytosolic $\mathrm{Ca}^{2+}$ and nitric oxide signaling in macula-densa-driven TG feedback [33, 37, 38]. Inscho and coworkers focused on cell $\mathrm{Ca}^{2+}$ and purinergic signaling $[28,30]$. It is clear that extracellular ATP signaling, $\mathrm{Ca}^{2+}$ signaling, and other signaling pathways may all play key roles in macula-densa-triggered TG feedback.

Having presented the above, it is also equally clear from the work of Schnermann and coworkers and others that ATP's metabolite, Ado, may also play an equally important role in TG feedback [32, 36-39]. They and others have long held the postulate that a local paracrine mediator within the confines of the JGA plays a key role in TG feedback. With early work with an arsenal of partially and more selective P1 Ado receptor antagonists, they focused on Ado [32, 36-39]. With mouse genetic approaches, they found that A1 Ado receptors (that signal via phospholipase $\mathrm{C}$ and cell $\mathrm{Ca}^{2+}$ like P2Y G-protein-coupled receptors and $\mathrm{P} 2 \mathrm{X}$ receptor channels) are absolutely required in the TG feedback mechanism [32, 36-39]. They also believe that the renin-angiotensin system plays a parallel role in TG feedback [36-39]. Garvin and coworkers showed in elegant work that ATP is indeed released by the macula densa in response to TG feedback signals in the cTAL; however, their careful work showed that the released ATP generates the production of adenosine $5^{\prime}$ monophosphate ( $5^{\prime}$ AMP) extracellularly in the JGA interstitium, which is used as a substrate to create Ado [37]. It is their belief that the metabolite Ado, is the key final mediator of the TG feedback mechanism [37]. Osswald et al., Vallon and others share this belief [39]. Having said that, Inscho et al., using $\mathrm{P} 2 \mathrm{X}_{1}$-receptor-channel-deficient mice $\left(\mathrm{P} 2 \mathrm{X}_{1}\right.$ is prominently expressed on vascular smooth muscle), have shown a similar deficit in TG feedback [30]. Taken together, we wonder if the kidney has chosen both ATP and Ado to achieve a fast, vigorous, complete, andpossibly-redundant TG feedback mechanism to ensure that this autoregulatory process remains intact. When such collegial controversy emerges, both camps are likely correct. For example, $\mathrm{P} 2 \mathrm{X}_{1}$ may mediate the effects on smooth muscle surrounding afferent arterioles, whereas Ado (and possibly ATP in parallel) may affect other cell types in the JGA to achieve full TG feedback. It is quite likely that more work will continue to emerge in this field.

Collecting duct: diuresis Following the logic above, intraluminal purinergic signaling would be robust in diuresis [46]. Vasopressin is not secreted, aquaporin-2 water channels are not inserted into the luminal membrane, and the collecting duct is virtually impermeable to water. As such, hypotonic free water would remain an osmotic or mechanical stimuli for ATP secretion from the macula densa to the urinary bladder. The ATP would be significant to high. Its metabolite Ado would also be present in significant amounts. The higher amounts of extracellular ATP ligand are consistent with its effects on sodium $\left(\mathrm{Na}^{+}\right)$and water $\left(\mathrm{H}_{2} \mathrm{O}\right)$ transport in renal collecting-duct epithelia and other ductal epithelia. Purinergic receptors attenuate epithelial sodium channel $(\mathrm{ENaC})$-mediated $\mathrm{Na}^{+}$absorption via multiple mechanisms [41-46]. In particular, Unwin and coworkers and Leipziger and colleagues have shown this elegantly in multiple in vivo, in-vivo-like, and in vitro model systems from kidney and other tissues [47-50]. In the most careful study examining a range of doses of Ado, Ado had a dual effect on $\mathrm{ENaC}$ : inhibition at high micromolar doses and stimulation at low nanomolar doses [44]. More recent work by Boucher and coworkers tied ATP and Ado to stimulation of anion secretion and inhibition of ENaC-mediated $\mathrm{Na}^{+}$absorption and the maintenance of airway surface liquid volume bathing multiciliated airway epithelium [51]. Along the same lines, Kishore and coworkers have shown elegantly that ATP attenuated vasopressin- and prostanoid-driven water permeability in collecting ducts [52-54]. They have also begun to address metabolism of ATP into its metabolites and their possible actions in collecting ducts.

Collecting duct: antidiuresis In antidiuresis, ATP and Ado would have only a finite amount of local signaling 
capability due to the free-water-driven bolus of secreted ATP entering the collecting-duct system. As the luminal tubular fluid osmolality rises due to water reabsorption in antidiuresis, ATP secretion would actually be attenuated and suppressed in areas of isoosmolality and hyperosmolality, respectively. Therefore, autocrine ATP and Ado signals would not be present, and $\mathrm{Na}^{+}$and $\mathrm{H}_{2} \mathrm{O}$ absorption could proceed vigorously without purinergic tonic inhibition.

Urinary bladder During the process of micturition or voiding, urine from the collecting-duct system stretches the urinary bladder as it is filled. Several groups have found that purinergic signaling underlies much of the physiology underlying the micturition process [55-83]. It begins with the urothelium being stretched by the expanding urinary bladder, causing stretch- or mechanical-dependent ATP release $[55,62,63,66,68,71,76,77]$. There are roles for both P2Y G-protein-coupled receptor and P2X receptor channels in the process $[59,61,62,64,65,67,70,72-75$, 79-83]. Their relative expression is visited below in a section of purinergic receptor expression along the nephron and urinary tract. However, it is P2X receptor channels that appear to play a more prominent role in the urinary bladder $[59,61,62,64,65,67,70,72-75,79-83]$. They are expressed on the urothelium along with $\mathrm{P} 2 \mathrm{Y}$ receptors. P2X receptors are also abundantly expressed on myofibroblasts and smooth muscle cells that surround the urinary bladder $[59,61,62,64,65,67,70,72-75,79-83]$. The stretchinduced ATP signal from the urothelium affects purinergic nerves of the urinary bladder to trigger action potentials that signal the need to void $[59,61,62,64,65,67,70,72-75$, 79-83]. This physiology has been proven in obstructeddetrusor-muscle models where purinergic and cholinergic signaling are upregulated artificially $[59,61,62,64,65,67$, 70, 72-75, 79-83]. Vanilloid- and capsaicin-driven receptors also play a role in these responses [66, 78, 80, 82]. Pain also emerged during obstruction to voiding, and it is partially $\mathrm{P} 2 \mathrm{X}$ receptor-channel-driven neurotransmission [83]. $\mathrm{P} 2 \mathrm{X}_{3}$ - and $\mathrm{P} 2 \mathrm{X}_{3} / \mathrm{P} 2 \mathrm{X}_{2}$-deficient mice have problems with the micturition response, proving these findings with mouse genetics [64, 65, 79, 83]. Chai and Sun have shown that ATP release and signaling process is heightened in interstitial cystitis (IC) $[63,77]$. There are also alterations in P2 receptor expression in IC [70, 74]. From this work, the nonselective purinergic receptor antagonist suramin has been suggested as an early lead therapeutics for IC, a chronic, painful, and debilitating syndrome [63]. P2X receptor channels may provide important targets for therapeutics that help with incontinence, IC and other related urinary disorders $[56,57,75,76,81]$. Perhaps it is the urinary bladder that is the most ideal paradigm along the nephron and urinary tract to study the importance of underlying autocrine and paracrine purinergic signaling.
It is therefore clear that autocrine and paracrine nucleotide and nucleoside signaling is robust and dynamic within the tubular lumen along the entire nephron and within and outside the urinary bladder. In addition to flow, osmotic, and mechanical stimuli discussed above, chemical stimuli could stimulate release of ATP along the entire nephron if a ligand is present that mobilizes cell calcium or cyclic nucleotides. Many active autocrine, paracrine, or endocrine ligands affect renal physiology, and any and all could trigger additional ATP secretion or Ado accumulation to that already filtered at the glomerulus or triggered by mechanical or osmotic stimuli. Figure 1 in its many forms shows the first principles of extracellular purinergic signaling as they pertain to the nephron and the kidney.

\section{Ecto-ATPases, Ecto-ADPases, and Ecto-5' nucleotidases along the nephron: generation of the active metabolite adenosine}

Knowledge of the expression of ecto-ATPases, ectoADPases, and ecto-5' nucleotidases in kidney is also accumulating, and it is critical to determine where extracellular nucleotide signals may diminish and extracellular nucleoside signals may be created [8-12, 16-18, 84, 85]. Less work has been done on ectokinases or secreted kinases that may phosphorylate adenine nucleosides to re-create ATP extracellularly. Elegant work on the extracellular surface of airway epithelia has documented the presence of these ectokinases. It is important not to rule out that they may be present along the nephron or in the urinary bladder. With regard to ecto-ATPases, Zimmerman and coworkers and Robson and colleagues are the foremost authorities in the field. Together with the emerging renal purinergic expert, Kishore, they documented expression of two prominent ecto-ATPases, nucleoside triphosphate diphosphohydrolase (NTPD)ase-1, an ecto-ATPase and ADPase that generates accumulating $5^{\prime}$ AMP, the precursor to Ado, and NTPDase-2, which converts ATP to ADP [8-12, 84, 85]. Both enzymes are related to CD39, an ectoapyrase that metabolizes both ATP and ADP [8-12, 84, 85]. Interestingly, these enzymes are most abundantly expressed in the renal vasculature and glomeruli [8-12, 84, 85]. The only principal nephron segment where nucleoside triphosphate diphosphohydrolase (NTPD)ase-1 was expressed was in the thin ascending limbs of the loops of Henle. Multiple studies have also shown that these ecto-NTPases and -NDPases are also enriched in microvillar membrane fractions of whole kidney. Additional ecto-NTPases have been cloned by Zimmerman and others and they are expressed in most if not all tissues including kidney [8-12, 84, 85].

These findings agree well with the work of a collaborative study by Schrader, Vallon, Zimmerman, and Osswald 
showing these enzymes expressed together with ecto-5'nucleotidase in a coordinated way to facilitate Ado production from secreted ATP so that Ado could be an active mediator of TG feedback within the JGA [8]. Kaissling and Le Hir studied comprehensively the expression and function of ecto-5'-nucleotidase in the kidney [16-18]. Initial work found abundant expression of 5 ' nucleotidase on fibroblasts within the interstitium of the renal cortical labyrinth. Subsequent work with a secondgeneration monoclonal antibody revealed that ecto-5'-nucleotidase was expressed on the brush border of proximal tubule segments and the apical membrane and apical cytoplasm of intercalated cells of all relevant segments of the collecting duct [16-18]. Interstitial stellate-shaped fibroblasts were also reactive [16-18]. Fibroblasts surrounding the afferent and efferent arterioles of the glomerulus were also positive [16-18]. However, Kaissling and Le Hir found that all parts of the JGA were negative [16-18]. As such, the glomerular fibroblasts may convert 5' AMP to Ado to aid TG feedback. However, it may be that intermediate metabolites of ATP, such as 5' AMP, may have important actions in TG feedback on P1 receptors that are not yet appreciated. It is important to note that extracellular 5' AMP and cyclic AMP are often abundant in extracellular samples. Receptors for these purine species have often been postulated; however, their existence has yet to be proven. We should not rule out that these purine metabolites or modified purine molecules may have specific receptors and receptor-mediated effects on renal physiology.

\section{Nucleotide and nucleoside receptor expression along the nephron}

No review of renal purinergic signaling would be complete without a summary of the current state of knowledge about nucleotide and nucleoside receptor expression in the kidney [86-108]. The study in 2003 by Turner et al. was perhaps the most comprehensive study of purinergic receptor expression to date. They assessed expression along the rat nephron of P2Y G-protein-coupled receptors 1, 2, and 4 . They coupled this with an assessment of the entire P2X receptor-channel subfamily, subtypes 1-7 [86]. In the vasculature, $\mathrm{P} 2 \mathrm{X}_{1}, \mathrm{P} 2 \mathrm{X}_{2}$, and $\mathrm{P}_{2} \mathrm{Y}_{1}$ expression was prominent. Within the glomerulus, $\mathrm{P}_{2} \mathrm{Y}_{1}$ was expressed on the mesangial cells, whereas $\mathrm{P}_{2} \mathrm{Y}_{2}$ was expressed on podocytes. $\mathrm{P} 2 \mathrm{X}_{1}$ and $\mathrm{P} 2 \mathrm{X}_{2}$ were present in smooth muscle cells of the glomerular vasculature, in agreement with the work of Inscho et al. [30] on TG feedback discussed above. In the proximal tubule, $\mathrm{P}_{2} \mathrm{Y}_{4}$ receptors were present only on the basolateral membrane and were absent from all other renal structures. Its exclusive expression of the basolateral surface of proximal tubules evokes a special physiological role that is yet to be appreciated. In contrast, apical surfaces of proximal straight tubule or $\mathrm{S} 3$ segments stained for $\mathrm{P}_{2} \mathrm{Y}_{1}$ and for $\mathrm{P} 2 \mathrm{X}_{5} . \mathrm{P} 2 \mathrm{X}_{4}$ and $\mathrm{P} 2 \mathrm{X}_{6}$ were expressed at lower levels; however, these two coassembling $\mathrm{P} 2 \mathrm{X}$ receptorchannel subtypes were expressed at lower but significant levels in all nephron segments, especially in proximal convoluted tubule and DCT. In the thin and thick ascending limbs of the loop of Henle, $\mathrm{P}_{2} \mathrm{Y}_{2}$ receptors were expressed mostly intracellularly. $\mathrm{P} 2 \mathrm{Y}_{2}$ receptors were also localized on intercalated cells of medullary but not cortical collecting ducts (CCDs). $\mathrm{P} 2 \mathrm{X}_{5}$ receptors were expressed in abundance on principal cells of the medullary collecting ducts, but $\mathrm{P}^{2} \mathrm{X}_{5}$ expression was diminished in the cortex. In these normal rat nephrons, $\mathrm{P}_{2} \mathrm{X}_{7}$ expression was not observed, save some low-level expression in only some glomeruli. Studies are presented below that both agree as well as depart from this seminal work. The authors do point out that they were unable to evaluate $\mathrm{P}_{2} \mathrm{Y}_{6}, \mathrm{P}_{2} \mathrm{Y}_{11}, \mathrm{P}_{2} \mathrm{Y}_{12}$, and $\mathrm{P} 2 \mathrm{Y}_{13}$ in this study due to lack of workable antibodies.

Much of the work performed previous to this study, and even studies performed subsequent to this study, relied on pharmacology as well as rank-order potency of a panel of different nucleotides, nucleosides, and analogs to determine which P2Y and P2X receptors may be expressed. Without any companion molecular biology and biochemistry to support the pharmacology and physiology, pharmacological studies of P2Y and P2X receptors can be misleading. Despite the wealth of literature arguing for selective effects of many purinergic agonists and antagonists, these ligands are rarely selective and often bind to multiple $\mathrm{P} 2 \mathrm{Y}$ and $\mathrm{P} 2 \mathrm{X}$ receptors to agonize or antagonize receptor activity. Together, these studies do, however, reveal a common theme shared by most, if not all, cells and tissues. This tenet is that there are usually one or more subtypes of the P2Y, $\mathrm{P} 2 \mathrm{X}$, and $\mathrm{P} 1$ receptor subfamilies expressed on any given renal vascular, glomerular, interstitial, or renal cell. One might not be able to define what subtypes are expressed precisely in all studies. However, the effects of purinergic ligands on a physiological endpoint are often quite dramatic and difficult to ignore.

Evidence for P2Y and P2X receptors in renal vasculature was found in a pharmacological study assessing nitric oxide (NO) production by Eltze and Ullrich [87]. There is abundant evidence for the expression of multiple P2Y and P2X receptors of vascular endothelium. Along these lines, Vonend et al. found messenger ribonucleic acid (mRNA) expression for P2X4-7 and P2Y1, 2, 4, 6, and 11 in glomerular epithelial cells [97]. Bailey et al. detected mRNA for P2Y1, 2, 4, and 6 in glomeruli that was confirmed by functional analysis using inositol phosphate production as an endpoint [90]. They confirmed $\mathrm{P}_{2} \mathrm{Y}_{1}$ receptor expression in the proximal tubule, showing inhibition of bicarbonate reabsorption [88]. They also 
assessed the expression of basolateral P2Y receptors along the nephron by applying different agonists to the bath in isolated nephron segment preparations [89]. Briefly, they found that ATP mobilized cell calcium in every nephron segment, with the exception of the TAL, which was unresponsive. They found evidence for $\mathrm{P}_{2} \mathrm{Y}_{1}, \mathrm{P}_{2} \mathrm{Y}_{2}$, and $\mathrm{P}_{2} \mathrm{Y}_{4}$ G-protein-coupled receptors on the basolateral surface of most nephron segments [89]. Schwiebert and colleagues assessed the expression of $\mathrm{P} 2 \mathrm{X}$ receptor-channel subtypes, with the exception of $\mathrm{P} 2 \mathrm{X}_{6}$, which could not be amplified with their degenerate reverse transcriptase polymerase chain reaction (RT-PCR) method [101]. In all normal cell models derived from known nephron segments, $\mathrm{P}_{2} \mathrm{X}_{4}$ and $\mathrm{P} 2 \mathrm{X}_{5}$ were shared in their abundant expression in multiple nephron segments [101]. P2 $\mathrm{X}_{6}$ is likely also expressed along most nephron segments, based on the work of Turner et al. from the Unwin laboratory [86]. In collecting duct-cell models, the expression pattern shifted to $\mathrm{P} 2 \mathrm{X}_{3}$ and $\mathrm{P} 2 \mathrm{X}_{4}$ as the most abundantly expressed members $[94,101]$. Schwiebert et al. also documented the appearance of $\mathrm{P}_{2} \mathrm{X}_{7}$ to a significant degree at the mRNA level in primary cultures of human polycystic kidney disease (PKD) cells versus non-PKD human renal epithelial cell primary cultures as controls [101]. In a collaborative study with McCoy and Stanton, they showed expression of $\mathrm{P}_{2} \mathrm{Y}_{1}$ and $\mathrm{P}_{2} \mathrm{Y}_{2}$ as well as $\mathrm{P} 2 \mathrm{X}_{3}$ and $\mathrm{P} 2 \mathrm{X}_{4}$ in mIMCD-K2 cells [94]. In studies in mouse DCT cells by Quamme and coworkers and by Wingo and coworkers in mIMCD-3 cells, expression and function of both $\mathrm{P} 2 \mathrm{Y}$ and $\mathrm{P} 2 \mathrm{X}$ purinoceptors was concluded [92, 93]. Taken together, it appears that renal epithelial cells that line most nephron segments express both functional P2Y G-protein-coupled receptors and P2X receptor channels.

Unwin and colleagues are emerging as the foremost authorities on purinergic receptor expression in normal and diseased kidneys. This is not surprising given their past tutelage in the Burnstock group. They have led the field in determining that $\mathrm{P} 2 \mathrm{X}_{7}$ expression emerges in apoptotic and/ or diseased renal epithelial, interstitial, and glomerular cells, which is well documented by several groups [86, 96, 98-100]. In particular, emergence of abundant $\mathrm{P} 2 \mathrm{X}_{7}$ expression has been documented in mouse models and in human cells and tissues within autosomal recessive (ARPKD) and autosomal dominant (ADPKD) polycystic kidney disease [96, 98-100]. In diabetic and hypertensive rats, $\mathrm{P} 2 \mathrm{X}_{7}$ expression emerged and was abundant in multiple vascular and nonvascular cell types of the glomerulus [96, 98-100]. It is important to note that activation of the $\mathrm{P} 2 \mathrm{X}_{7}$ receptor channel also evokes the appearance of the opening of large pores that allow dyes to enter cells and that are used to detect apoptotic cells. There is debate about whether the $\mathrm{P} 2 \mathrm{X}_{7}$-channel pore undergoes a conformational change or dilation to conduct these dyes itself or whether it activates a separate membrane proteindriven pathway via second messengers and mitogenactivated protein (MAP) kinase and other kinases [109]. It also remains unclear to the authors whether $\mathrm{P}_{2} \mathrm{X}_{7}$ is a critical player in the beginnings of apoptosis or whether it is upregulated as a consequence of apoptosis and is therefore an important marker of programmed cell death.

It is important to mention that there have been a series of studies using apically applied ligands to study the luminal effects of purinergic ligands on $\mathrm{Na}^{+}$and $\mathrm{H}_{2} \mathrm{O}$ transport and other endpoints. Based upon this work, these groups have concluded that $\mathrm{P} 2 \mathrm{U}$ or $\mathrm{P}_{2} \mathrm{Y}_{2}$ receptors are the main luminal receptors involved [102-105]. However, based upon the work above where parallel molecular, biochemical, and immunocytochemical work was performed with physiology, it is not at all clear that $\mathrm{P}_{2} \mathrm{Y}_{2}$ is solely involved or involved at all. This is where care as well as more comprehensive studies are needed to confirm that $\mathrm{P}_{2} \mathrm{Y}_{2}$ is a chief luminal purinoceptor in kidney.

In renal epithelial cell models such as Madin-Darby canine kidney (MDCK) cells and A6, purinergic receptor expression has also been assessed. Here, P2Y receptors have been the main focus, and work on P2X receptors has been less addressed. Insel and coworkers found evidence for $\mathrm{P}_{2} \mathrm{Y}_{1}, \mathrm{P}_{2} \mathrm{Y}_{2}$, and $\mathrm{P} 2 \mathrm{Y}_{11}$ [106]. In MDCK cells, Ostrom et al. performed some seminal mechanical perturbation studies showing marked effects on ATP release [110]. Ado receptor studies have also been performed on these wellknown renal cell lines, mostly with regard to regulation of $\mathrm{ENaC}$ [41-44]. Ado receptors were not identified in these studies. However, as with P2 receptors, it is shared knowledge that both $\mathrm{A} 1$ and A2 Ado receptors are expressed on these renal cell models and on most nephron segments. Vitzthum et al. showed that A1 Ado receptors and A2a Ado receptors had marked expression in the cortex that was less prominent in the medulla [107]. A2b Ado receptor expression was weak throughout renal tissue [107]. A1 receptors were expressed strongly in the thin limbs of Henle and in the collecting duct system [107]. A2a receptor expression was strong in glomeruli. A2b expression within specific segments was prominent in cTAL and in DCT [107]. A3 receptors were not found in any tissue of the kidney [107]. Interestingly, in urinary bladder, Apodaca and coworkers found that all four P1 Ado-sensing G-proteincoupled receptors (A1, A2a, A2b, and A3) are expressed in the urothelium, as determined by Western blot [60]. Ado increased membrane capacitance of both the apical and basolateral membranes of the urothelium, suggesting that Ado stimulates exocytosis. A1 receptors were most active in the capacitance increase, an electrical measure of membrane area.

Table 1 provides a synopsis of the above literature with regard to expression of $\mathrm{P} 2 \mathrm{Y}, \mathrm{P} 2 \mathrm{X}$, and $\mathrm{P} 1$ receptors along 
Table 1 Nucleotide and nucleoside receptor expression along the nephron

\begin{tabular}{llll}
\hline & ATP-sensing P2Y GPCRs ATP-gated & ATP-gated P2XR Channels & Ado-sensing P1 GPCRs \\
\hline $\begin{array}{lll}\text { Glomerulus } \\
\text { Podocytes }\end{array}$ & P2Y1, P2Y2, P2Y4, P2Y6, P2Y11 & P2X4, P2X5, P2X6, P2X7 & A2a, A2b \\
Mesangium & P2Y2 & & \\
VSM Cells & P2Y1 & P2X1, P2X2 & A2b \\
PCT & P2Y1 & P2X4, P2X5, P2X6 & A2b \\
PST & P2Y4 & P2X4, P2X5, P2X6 & A1, A2b \\
Thin limbs & P2Y1, P2Y4 & P2X4, P2X6 & A2b \\
mTAL/cTAL & P2Y2 & P2X4, P2X5, P2X6 & A2b \\
DCT & P2Y2 & P2X4, P2X6 & A1, A2b \\
CCD & & P2X3, P2X4, P2X5, P2X6 & A1, A2b \\
OMCD & & P2X4, P2X6 & P2X3, P2X4, P2X5, P2X6 \\
IMCD & P2Y2 & & A2b \\
Urinary bladder & P2Y1, P2Y2 & & $\mathbf{A 1 , ~ A 2 a , ~ A 2 b , ~ A 3 ~}$ \\
Urothelium & P2YRs & & P2X2, P2X3 \\
Myofibroblasts & & & \\
Urinary neurons & & & \\
\hline
\end{tabular}

Bold indicates a prominent signal in molecular, biochemical, or immunohistochemical terms

the nephron. It also illustrates that each cell and segment within the kidney express at least one P2Y nucleotidesensing G-protein-coupled receptor, one nucleotide-gated $\mathrm{P} 2 \mathrm{X}$ receptor channel, and at least one P1 nucleosidesensing G-protein-coupled receptor. The implications of this for health and disease, knowing that ATP and Ado are likely secreted and produced in the tubular lumen and the interstitium, are discussed in more detail below.

\section{More ideal purinergic microenvironments in remodeled polycystic kidney tissue: a normal purinergic signaling paradigm in an open system becomes detrimental in a closed system}

Again, in first-principle terms, purinergic ligands are most potent as local mediators or autocoids [111-123]. They can be potent as paracrine factors; however, diffusion away from the source as well as degradation limits their potency. Purinergic agonists in vivo are not efficient as blood-borne mediators [111-124]. ATP is degraded rapidly in the general circulation via multiple membrane-bound and secreted ecto-ATPases [111-124]. With regard to purinergic signaling, it is now comprehensively appreciated that: (1) all cells release ATP from small releasable pools that account for $0.1 \%$ or less of the total intracellular ATP content (up to $10 \mu \mathrm{M}$ detectable secreted ATP from 5$10 \mathrm{mM}$ total intracellular ATP) [111-127]; (2) all cells express one or more subtypes of the ATP-gated P2X receptor channels, ATP-sensing P2Y G-protein-coupled receptors, and Ado-sensing P1 G-protein-coupled receptors [111-136]; and (3) all cells are influenced by purinergic ligands via these receptors in similar and different ways
[111-136]. Ado is recycled back into cells via nucleoside transporters to be used for ATP resynthesis [111-136]. It is generally agreed upon that purinergic ligand activity is short lived and the ability of ATP or Ado to bind to and signal via its many cell-surface receptors is most robust in tissue microenvironments.

Purinergic signaling and ADPKD The normal renal tissue microenvironments are conducive to autocrine and paracrine purinergic signaling. However, they remain open systems where the tubular fluid enters and leaves a nephron segment and the final urine exits the kidneys and empties into the urinary bladder. Remodeled kidney tissue that occurs in cystic disease and PKD can present an even more ideal purinergic signaling microenvironment. In presenting ADPKD - a progressive disease of remodeling that does not present until the early to middle decades of adulthoodends of renal tubules, bile ducts, pancreatic ducts, and renal collecting ducts pinch off at each end, creating a cyst that has lost contact and communication from the rest of the nephron. The cyst is then fully encapsulated by a single monolayer of cystic epithelial cells. Whereas the initial stages of the disease involve and require remodeling, the disease progression observed in ADPKD is quite heterogeneous. It is likely that epigenetic factors not directly associated with mutated genes or proteins contribute substantially in this secondary phase of the disease that could be termed the progression phase of ADPKD. In an encapsulated cyst, the microenvironment or system is closed. The process of ATP release and autocrine ATP signaling that normally was significant in an open system such as a renal tubule is now trapped in the closed lumen of an ADPKD cyst. The newly remodeled and pathophysio- 
logical microenvironment converts acute purinergic signaling into chronic purinergic signaling.

In past work, our laboratory showed that ATP content was robust in a subset of cyst fluid samples from ADPKD kidneys [123]. We also showed that ADPKD cell monolayers released ATP across the apical membrane as or more readily than normal kidney-cell monolayers [123, 124]. This work was almost exclusively performed on primary cultures of human kidney cells grown as polarized cell monolayers. We also showed that multiple P2X and P2Y purinergic receptor subtypes were expressed by normal and ADPKD primary human-cell monolayers and that nucleotide ligands to both types of $\mathrm{P} 2$ receptors could increase cell $\mathrm{Ca}^{2+}$ and stimulate chloride $\left(\mathrm{Cl}^{-}\right)$secretion [124]. We did not examine intraluminal Ado signaling; however, we speculated that Ado would accumulate and also be deleterious. Purinergic receptor-driven stimulation of $\mathrm{Cl}^{-}$ secretion by ATP and by Ado has been well documented in MDCK cells as well as in other renal epithelial cell model systems from the collecting duct and in many other epithelial cell and tissue models [137-151]. The cystic fibrosis (CF) transmembrane conductance regulator (CFTR) $\mathrm{Cl}^{-}$channel is often expressed in cyst-lining renal epithelial cells and may contribute to cyst-fluid accumulation and expansion [137-151]. It may also be detrimental in cystfluid accumulation and expansion [137-151]. Mouse models of ADPKD have been crossed recently with CF mice to test this hypothesis with mouse genetics by Calvet, Wallace and coworkers at the University of Kansas Medical Center's Kidney Institute. Indeed, the results show now with the correct genetic cross that CFTR and cyclic-AMP (cAMP)-driven $\mathrm{Cl}^{-}$secretion and signaling are detrimental to cAMP-driven cyst formation and expansion in mice (DP Wallace, personal communication). This paper confirms previous physiological studies with powerful mouse transgenic technology to show that normal $\mathrm{Cl}^{-}$secretory processes within the collecting duct can also be detrimental when the tissue is remodeled and encapsulated.

From this abundant work by others and by us, we argued that autocrine and paracrine ATP and Ado signaling could be detrimental to ADPKD cyst growth and expansion [111151]. The detrimental pathophysiological effects could be the continual stimulation of $\mathrm{Cl}^{-}$and fluid secretion into the encapsulated cysts and/or the chronic mitogenic effects on the cells that lined the encapsulated cysts. Not only could this be detrimental to the progression of ADPKD cysts in the kidney, but it could also play a deleterious role in cysts observed in extrarenal tissues in ADPKD as well as in polycystic syndromes in other tissues, such as ovary and breast [152], where $\mathrm{P} 2 \mathrm{Y}$ and $\mathrm{P} 2 \mathrm{X}$ receptors are also expressed. Having said that, autocrine and paracrine purinergic signaling may play a very different role in ARPKD where encapsulated cysts rarely form and only dilation of renal collecting ducts and biliary duct is observed in the human disease [153-155]. ARPKD and ADPKD are very different diseases with respect to the type of tissue remodeling that occurs [153-155]; this is an important caveat that needs to be voiced.

There was a reemergence of work in purinergic signaling in renal epithelial cell model systems and in liver cyst preparations in 2006. Turner et al. used a three-dimensional collagen gel culture system in which MDCK cells were seeded into this gel matrix as it forms [122]. The cells organized into cyst structures and grew and expanded in diameter and volume over time in vitro within this gel matrix. Turner et al. showed elegantly and comprehensively that release of endogenous purinergic ligands into the microenvironment surrounding and within these MDCK cell cysts drove their growth and expansion. Use of the ATP and ADP scavenger apyrase, as well as some nonspecific antagonists of P2 receptors, inhibited cyst expansion markedly. Inhibitors of the extracellular signal-regulated kinases (ERK) slow cyst growth and expansion more dramatically. Both $\mathrm{P} 2 \mathrm{Y}$ and $\mathrm{P} 2 \mathrm{X}$ receptors can trigger ERK activation [156-158], as can growth factor receptors [159]. It is well known that purinergic receptor systems can transactivate growth factor receptor systems and cytokine receptor systems $[134,160]$. It is well known that purinergic ligands can act as mitogens in their own right or comitogens with growth factors. As illustrated [122] and discussed in the PKD literature above, the interplay between local purinergic signaling and growth factor signaling may be critically important in the progression of PKD during remodeling and after cysts have formed. The monocilium of the ductal epithelium and the protein products of genes mutated in PKD may have a central galvanizing role in purinergic and growth factor signaling crosstalk [161-181].

In cystic ductal epithelial cells from the livers of mouse models of ARPKD and ADPKD [182], Doctor, Gattone, Fitz, and coworkers studied the regulation of ion transport in cystic cholangiocytes by purinergic ligands and receptors. Bile duct epithelia (BDE) encapsulating liver cysts are positioned to govern cyst expansion, much like the renal cystic epithelial cells lining renal cysts. Once the cyst has formed, the detrimental purinergic signaling paradigm likely has shared characteristics from tissue to tissue. These authors found that there was robust anion secretion and sodium absorption under basal conditions in these cystic BDE monolayers grown in primary culture from isolated liver cysts. It is laborious work to isolate cholangiocytes from cystic structures. It was not possible to harvest enough noncystic cholangiocytes from isolated bile duct units for comparison of unaffected and affected tissue. However, the authors did show that elevation of cAMP agonists or extracellular nucleotides induced robust $\mathrm{Cl}^{-}$secretion. They also showed the presence of a key purinergic receptor, the 


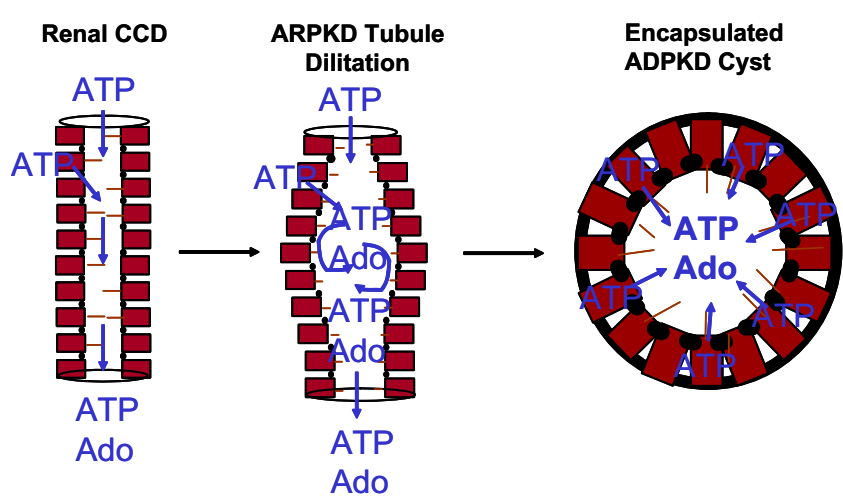

Fig. 2 Purinergic signaling in an encapsulated ADPKD cyst. The progression of remodeling in ARPKD versus ADPKD is shown in diagram format. Whereas some longer-lived extracellular ATP and adenosine (Ado) signaling may occur in dilated ARPKD segments, ADPKD cysts have lost communication with the rest of the nephron when encapsulated

$\mathrm{P} 2 \mathrm{X}_{4}$ receptor channel, on the cystic BDE. Importantly, as in our ADPKD renal cyst fluid studies, these investigators also found significant ATP levels in a subset of cyst fluid samples. They also went a step beyond our former study by applying cyst fluid to the apical surface of cystic BDE cell monolayers. For those cyst fluids that stimulated anion secretion, the ATP and ADP scavenger apyrase, an NTPase/ NDPase, abolished the stimulatory effects of the cyst fluid, illustrating that the active mediator was indeed, either ATP, UTP, ADP, or UDP.

Figure 2 illustrates trapped purinergic signaling in encapsulated ADPKD cysts. It is our hope that the ADPKD research community applies these findings to collagen gel studies of primary human ADPKD cell cysts or to kidney organ culture models where cyst formation can be visualized. In these models, it is also highly likely that antagonism of local purinergic signaling may slow cyst progression and that existing as well as novel therapeutics may be brought to bear on ADPKD pathogenesis.

Purinergic signaling in ARPKD As mentioned briefly above, ARPKD is a very different disease in its presentation and in its tissue remodeling. ARPKD presents in utero and in the neonatal period. Patients who survive the early neonatal period (a significant number do not because of respiratory insufficiency due to respiratory hypoplasia) uniformly develop severe and debilitating hypertension. It is our view that upregulated $\mathrm{Na}^{+}$hyperabsorption may also explain respiratory hypoplasia; however, this postulate will be difficult to prove [155]. The underlying etiology of this hypertension may be upregulated $\mathrm{Na}^{+}$absorption in the collecting duct, as evidenced by Satlin and coworkers as well as our laboratory [155]. However, in contrast to ADPKD, renal tubules and bile ducts dilate and are deemed as pseudocysts in ARPKD; however, they rarely if ever pinch off and form fully encapsulated cysts. As such, the pathophysiological tissue system remains open. Perhaps, $\mathrm{Na}^{+}$hyperabsorption prevents full remodeling. Nevertheless, purinergic signaling may be robust in areas of the pseudocysts where there are unstirred layers or areas of turbulent flow. Purinergic signaling could drive detrimental $\mathrm{Cl}^{-}$secretion to cause expansion of these pseudocysts. Since purinergic signaling and its possible detrimental role is being reexamined in ADPKD, purinergic signaling should also be examined in ARPKD.

Having said that, laboratories have become obsessed with the cell biology and physiology of the monocilium in both forms of PKD [161-181]. In particular, we and others have investigated the roles of the monocilium, flow, and

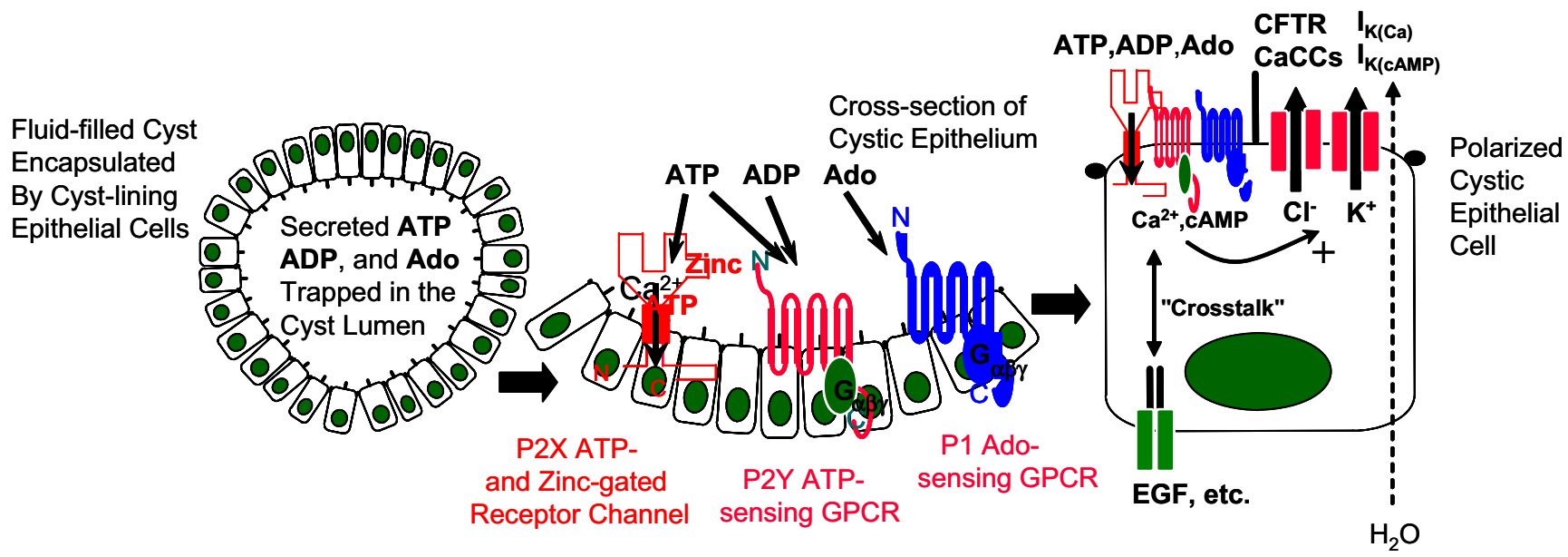

Fig. 3 Postulated detrimental roles of purinergic signaling in an ARPKD pseudocyst or ADPKD cyst. Although ARPKD pseudocysts are not fully encapsulated, they may close off periodically due to limits in space between noncystic and cystic tissue parenchyma, leading to similar problems that occur in ADPKD encapsulated cysts.
Adenosine stimulation of cyclic AMP and cystic fibrosis transmembrane-conductance-regulator (CFTR)-driven salt and water secretion and ATP stimulation of calcium-driven salt and water secretion are pictured, and both may proceed in parallel to the detriment of volume expansion in the cysts 
autocrine ATP signals in renal cell models of the collecting duct. In particular, cilium-dependent $\mathrm{Ca}^{2+}$ signals have been in sharp focus. Taken together, it is clear that mechanically induced $\mathrm{Ca}^{2+}$ signals are partially attenuated when the cilium is missing and that the cilium-derived $\mathrm{Ca}^{2+}$ signal derives from both $\mathrm{Ca}^{2+}$ entry from extracellular stores and $\mathrm{Ca}^{2+}$ release from intracellular stores. For the latter $\mathrm{Ca}^{2+}$ release source, it is postulated that there is a $\mathrm{Ca}^{2+}$ store near the monocilium and the basal body that may be coupled to the plasma membrane. It is clear that a flow stimulus or a physical bending of the monocilium sparks a $\mathrm{Ca}^{2+}$ transient. If the $\mathrm{Ca}^{2+}$ spark or transient is robust enough, it can trigger a $\mathrm{Ca}^{2+}$ wave across many cells within a monolayer or tubule or duct. However, it is also well known that autocrine and paracrine purinergic signaling can propagate $\mathrm{Ca}^{2+}$ signals or waves. Satlin and coworkers showed in isolated perfused CCDs from $T g 737^{\circ r p k}$ mice that the monocilium was indeed required for a full flow-induced $\mathrm{Ca}^{2+}$ signal [183]. They did not assess a role for underlying autocrine purinergic signaling. In contrast, Leipziger and colleagues assessed pressure-pulse-induced $\mathrm{Ca}^{2+}$ signaling in nonciliated (immature) and ciliated (mature) MDCK cells [184]. This laboratory found pressure-pulse-induced $\mathrm{Ca}^{2+}$ signals from both MDCK cell preparations and showed that purinergic signaling played a direct role in the $\mathrm{Ca}^{2+}$ signal observed.

Although this pressure pulse is a different mechanical stimulus than flow, we sought to rectify these partially opposing results with our preparation of cilium-deficient versus cilium-competent $\mathrm{CCD}$ principal cell monolayers from the $T g 737^{o r p k}$ mouse model of cystic kidney disease. Indeed, flow-induced $\mathrm{Ca}^{2+}$ signals were significantly more robust in cilium-competent cell monolayers versus ciliumdeficient cell monolayers. However, infusion of gadolinium $\mathrm{Cl}^{-}$or apyrase abolished the flow-induced $\mathrm{Ca}^{2+}$ signal in cilium-competent cell monolayers. We also examined basal versus stimulated ATP release in both principal cell models. Basal ATP release across the apical cell membrane was not different between cilium-deficient and cilium-competent cell monolayers. Basolateral ATP release was negligible in both preparations. However, stimulated ATP release by mechanical perturbation, hypotonic cell swelling, and cytosolic calcium mobilization was greatly attenuated in cilium-deficient cell monolayers versus cilium-competent cell monolayers. An accompanying paper in this issue shows these results in detail. We hypothesize that both the monocilium and an autocrine ATP signal are critical for the monocilium-derived $\mathrm{Ca}^{2+}$ signal. We postulated that a releasable ATP pool and a $\mathrm{Ca}^{2+}$ store may be dedicated to the monocilium of a fully differentiated ductal epithelial cell. When both are missing due to a lost or dysfunctional cilium, monocilium-derived signaling may be lost, leading to heightened $\mathrm{Na}^{+}$absorption via multiple mechanisms as well as the myriad additional effects on cell proliferation, remodeling, extracellular matrix deposition, regulation of cell polarity, and gene regulation.

Figure 3 provides a diagram illustrating the detrimental epigenetic role that trapped purinergic signaling may play in the secondary progression of ADPKD after remodeling. Mitogenic effects of purinergic signaling, as well as crosstalk with growth factor receptor signaling (also aberrant in PKD), is also illustrated. With emergence of new studies seeking to define this hypothesis, it is quite likely that purinergic receptors may be viable therapeutic targets to attenuate secondary ADPKD disease progression.

\section{Future directions}

Through writing this review, it became more clear to us that purinergic signaling plays essential roles in normal renal physiology - from the glomerulus to the urinary bladder. There is also emerging clarity that trapped purinergic signaling mediated by both ATP and Ado may, indeed, be a detrimental epigenetic factor in the acceleration of progression of ADPKD. More definitive work on purinergic signaling is required in ARPKD to assess any possible detrimental contribution. We hope this review induces other laboratories, as well as our own, to continue to define renal purinergic signaling in health and disease.

Acknowledgments We acknowledge the support of DK67343 to EMS and the Recessive PKD Research and Translational CORE Centers P30 Program for support of our PKD research. We acknowledge the support of the Department of Physiology and Biophysics and the Cellular and Molecular Physiology Graduate Program to $\mathrm{MBH}$.

\section{References}

1. Dietrich HH, Ellsworth ML, Sprague RS, Dacey RG Jr (2000) Red blood cell regulation of microvascular tone through adenosine triphosphate. Am J Physiol 278:H1294-H1298

2. Sprague RS, Ellsworth ML, Stephenson AH, Lonigro AJ (2001) Participation of CAMP in a signal-transduction pathway relating erythrocyte deformation to ATP release. Am J Physiol 281: C1158-C1164

3. Oleaeczyk JJ, Ellsworth ML, Stephenson AH, Linigro AJ, Sprague RS (2004) Nitric oxide inhibits ATP release from erythrocytes. J Pharmacol Exp Ther 309:1079-1084

4. Guyton AC, Hall JE (2000) Textbook of medical physiology, 10th edn. WB Saunders, Philadelphia, PA

5. Johnson LR (2003) Essential medical physiology, 3rd edn. Elsevier Academic Press, New York, NY

6. Koeppen B, Stanton BA, Levy MN, Berne RM (2002) Physiology, 4th edn. CV Mosby, St. Louis, MO

7. Thomson S, Bao D, Deng A, Vallon V (2000) Adenosine formed by $5^{\prime}$-nucleotidase mediates tubuloglomerular feedback. J Clin Invest 106(2):289-298 
8. Huang DY, Vallon V, Zimmerman H, Koszalka P, Schrader J, Osswald H (2006) Ecto-5'-nucleotidase (CD73)-dependent and -independent generation of adenosine participates in the mediation of tubuloglomerular feedback in vivo. Am J Physiol 291:F282-F288

9. Kishore BK et al (2005) Expression of NTPDase1 and NTPDase2 in murine kidney: relevance to regulation of P2 receptor signaling. Am J Physiol 288:F1032-F1043

10. Valenzuela MA et al (1996) Comparison of the biochemical properties, regulation and function of ATP-diphosphohydrolase from human placenta and rat kidney. Braz J Med Biol Res 29:589-597

11. Sandoval S et al (1996) ATP-diphosphohydrolase activity in rat renal microvillar membranes and vascular tissue. Int J Biochem Cell Biol 28:591-599

12. Kegel B, Braun N, Heine P, Maliszewski CR, Zimmerman H (1997) An ecto-ATPase and an ecto-ATP diphosphohydrolase are expressed in rat brain. Neuropharmacology 36:1189-1200

13. Schwiebert EM, Liang L, Cheng NL, Olteanu D, Williams CL, Welty EA, Zsembery A (2005) Extracellular ATP- and zincgated P2X receptor calcium entry channels: physiological sensors and therapeutic targets. Purinergic Signal 1(4):299-310

14. Schwiebert EM, Zsembery A (2003) Extracellular ATP as a signaling molecule for epithelial cells. Biochim Biophys Acta 1615:7-32

15. Schwiebert EM, Kishore BK (2001) Extracellular purinergic signaling along the renal epithelium. Am J Physiol 280:F945F963

16. Le Hir M, Kaissling B (1993) Distribution and regulation of renal ecto-5'-nucleotidase: implications for physiological functions of adenosine. Am J Physiol 264:F377-F387

17. Le Hir M, Kaissling B (1989) Distribution of $5^{\prime}$ nucleotidase in the renal interstitium of the rat. Cell Tissue Res 258:177-182

18. Gandhi R, Le Hir M, Kaissling B (1990) Immunolocalization of ecto-5'-nucleotidase in the kidney by a monoclonal antibody. Histochemistry 95:165-174

19. Burnstock G (2006) Purinergic signaling. Br J Pharmacol 147: S172-S181

20. Erb L, Liao Z, Seye CI, Weisman GA (2006) P2 receptors: intracellular signaling. Pflugers Arch 452:552-562

21. Jacobsen KA, Gao ZG (2006) Adenosine receptors as therapeutic targets. Nat Rev Drug Discov 5:247-264

22. Notenboom $S$ et al (2006) Increased apical insertion of the multidrug resistance protein 2 (MRP2/ABCC2) in renal proximal tubules following gentamicin exposure. J Pharmacol Exp Ther 318:1194-1202

23. Huls $\mathrm{M}$ et al (2006) ABC transporter expression profiling after ischemic reperfusion injury in mouse kidney. Kidney Int 69:2186-2193

24. Schlatter P, Gutmann H, Drewe J (2006) Primary porcine proximal tubular cells as a model for transepithelial drug transport in human kidney. Eur J Pharm Sci 28:141-154

25. Imaoka $T$ et al (2004) The renal-specific transporter mediates facilitative transport of organic anions at the brush border membrane of mouse renal tubules. A Am Soc Neph 15:21122022

26. Braunstein GM, Zsembery A, Tucker TA, Schwiebert EM (2004) Purinergic signaling underlies CFTR control of human airway epithelial cell volume. J Cyst Fibros 3(2):99-117

27. Braunstein GM, Roman RM et al (2001) CFTR facilitates ATP release by stimulating a separate ATP release channel for autocrine regulation of cell volume. J Biol Chem 276(9):6621-6630

28. White SM, Imig JD, Kim TT, Hauschild BC, Inscho EW (2001) Calcium signaling pathways utilized by $\mathrm{P} 2 \mathrm{X}$ receptors in freshly isolated preglomerular MVSMC. Am J Physiol 280(6):F1054F1061
29. Ren Y, Arima S, Carretero OA, Ito S (2002) Possible role of adenosine in macula densa control of glomerular hemodynamics. Kidney Int 61(1):169-176

30. Inscho EW, Cook AK, Imig JD, Vial C, Evans RJ (2003) Physiological role for $\mathrm{P} 2 \mathrm{X} 1$ receptors in renal microvascular autoregulatory behavior. J Clin Invest 112(12):1895-1905

31. Komlosi P et al (2004) Macula densa basolateral ATP release is regulated by luminal $[\mathrm{NaCl}]$ and dietary salt intake. Am J Physiol 286(6):F1054-F1058

32. Zhao $X$ et al (2005) Impaired calcium signaling attenuates P2X receptor-mediated vasoconstriction of afferent arterioles in angiotensin II hypertension. Hypertension 46(3):562-568

33. Silva G, Beierwaltes WH, Garvin JL (2006) Extracellular ATP stimulates NO production in rat thick ascending limb. Hypertension 47(3):563-567

34. Kim SM, Mizel D, Huang YG, Briggs JP, Schnermann J (2006) Adenosine as a mediator of macula densa-dependent inhibition of rennin secretion. Am J Physiol 290:F1016-F1023

35. Peti-Peterdi J (2006) Calcium wave of tubuloglomerular feedback. Am J Physiol 291:F473-F480

36. Schnermann J, Levine DZ (2003) Paracrine factors in tubuloglomerular feedback: adenosine, ATP, and nitric oxide. Annu Rev Physiol 65:501-529

37. Ren Y, Garvin JL, Liu R, Carretero OA (2004) Role of macula densa ATP in tubuloglomerular feedback. Kidney Int 66:14791485

38. Ren Y, Liu R, Carretero OA, Garvin JL (2003) Increased intracellular calcium in the macula densa regulates tubuloglomerular feedback. Kidney Int 64:1348-1355

39. Osswald H, Muhlbauer B, Schenk F (1991) Adenosine mediated tubuloglomerular feedback response: an element of metabolic control of kidney function. Kidney Int 32:S128-S131

40. Bell PD et al (2003) Macula densa cell signaling involves ATP release through a maxi anion channel. Proc Natl Acad Sci USA 100:4322-4327

41. Wei $\mathrm{Y}$ et al (2006) Adenosine inhibits $\mathrm{ENaC}$ via cytochrome P450 epoxygenase-dependent metabolites of arachidonic acid. Am J Physiol 290:F1163-F1168

42. Kunzelmann K et al (2005) Purinergic inhibition of the epithelial sodium transport via hydrolysis of PIP2. FASEB J 19:142-143

43. Ma HP, Li L, Zhou ZH, Eaton DC, Warnock DG (2002) ATP masks stretch activation of epithelial sodium channels in A6 distal nephron cells. Am J Physiol 282:F501-F505

44. Ma H, Ling BN (1996) Luminal adenosine receptors regulate amiloride-sensitive $\mathrm{Na}^{+}$channels in A6 distal nephron cells. Am J Physiol 270:F798-F805

45. Olteanu D et al (2006) Heightened ENaC-mediated sodium absorption in a murine polycystic kidney disease model epithelium lacking apical monocilia. Am J Physiol 290:C952-C963

46. Falin R, Veizis IE, Cotton CU (2005) A role for ERK1/2 in EGFand ATP-dependent regulation of amiloride-sensitive sodium absorption. Am J Physiol 288:C1003-C1011

47. Shirley DG, Bailey MA, Unwin RJ (2005) In vivo stimulation of apical P2 receptors in collecting ducts: evidence for inhibition of sodium reabsorption. Am J Physiol 288:F1243-F1248

48. Leipziger J (2003) Control of epithelial transport via luminal P2 receptors. Am J Physiol 284:F419-F432

49. Lehrmann H, Thomas J, Kim SJ, Jacobi C, Leipziger J (2002) Luminal P2Y2 receptor-mediated inhibition of sodium absorption in isolated perfused mouse CCD. J Am Soc Neph 13:10-18

50. Thomas J, Deetjen P, Ko WH, Jacobi C, Leipziger J (2001) P2Y2 receptor-mediated inhibition of amiloride-sensitive short circuit current in M-1 mouse cortical collecting duct cells. J Membr Biol 183:115-124

51. Tarran R, Trout L, Donaldson SH, Boucher RC (2006) Soluble mediators, not cilia, determine airway surface liquid volume in 
normal and cystic fibrosis superficial airway epithelia. J Gen Physiol 127:591-604

52. Kishore BK et al (2005) P2Y2 receptor mRNA and protein expression is altered in inner medulla of hydrated and dehydrated rats: relevance to AVP-independent regulation of IMCD function. Am J Physiol 288:F1164-F1172

53. Sun $\mathrm{R}$ et al (2005) Chronic dDAVP infusion in rats decreases the expression of $\mathrm{P} 2 \mathrm{Y} 2$ receptor in inner medulla and $\mathrm{P} 2 \mathrm{Y} 2$ receptor-mediated PGE2 release in IMCD. Am J Physiol 289: F768-F776

54. Sun R, Carlson NG, Hemmert AC, Kishore BK (2005) P2Y2 receptor-mediated release of prostaglandin E2 by IMCD is altered in hydrated and dehydrated rats: relevance to AVPindependent regulation of IMCD function. Am J Physiol 289: F585-F592

55. Lewis SA, Lewis JR (2006) Kinetics of urothelial ATP release. Am J Physiol 291:F332-F340

56. Fabiyi AC, Brading AF (2006) The use of the isolated mouse whole bladder for investigating bladder overactivity. J Pharmacol Exp Ther 319(3):1386-1394

57. Steers W (2001) Potential targets in the treatment of urinary incontinence. Rev Urol 3:S19-S26

58. Werner ME et al (2006) Frequency encoding of cholinergic- and purinergic-mediated signaling to mouse urinary bladder smooth muscle: modulation by BK channels. Am J Physiol 292(1): R616-R624

59. Sui G, Wu C, Fry CH (2006) Characterization of the purinergic receptor subtype on guinea-pig suburothelial myofibroblasts. BJU Int 97:1327-1331

60. Yu W, Zacharia LC, Jackson EK, Apodaca G (2006) Adenosine receptor expression and function in bladder uroepithelium. Am J Physiol 291:C254-C265

61. Ruan NZ et al (2006) Expression of P2X and P2Y receptors in the intramural parasympathetic ganglia of the cat urinary bladder. Am J Physiol 290:F1143-F1152

62. Wang EC et al (2005) ATP and purinergic receptor-dependent membrane traffic in bladder umbrella cells. J Clin Invest 115 (9):2412-2422

63. Sun Y, Chai TC (2006) Augmented extracellular ATP signmaling in bladder urothelial cells from patients with interstitial cystitis. Am J Physiol 290:C27-C34

64. Cockayne DA et al (2005) P2X2 knockout mice and P2X2/P2X3 double knockout mice reveal a role for the $\mathrm{P} 2 \mathrm{X} 2$ receptor subunit in mediating multiple sensory effects of ATP. J Physiol 567:621-639

65. Studeny S, Torabi A, Vizzard MA (2005) P2X2 and P2X3 receptor expression in postnatal and adult rat urinary bladder and lumbosacral spinal cord. Am J Physiol 289:R1155-R1168

66. Atiemo H, Wynes J, Chuo J, Nipkow L, Sklar GN, Chai TC (2005) Effect of botulinum toxin on detrusor overactivity induced by intravesical ATP and capsaicin in a rat model. Urology 65(3):622-626

67. Heppner TJ, Bonev AD, Nelson MT (2005) Elementary purinergic calcium transients evoked by nerve stimulation in rat urinary bladder smooth muscle. J Physiol 564:201-212

68. de Groat WC (2004) The urothelium in overactive bladder: passive bystander or active participant? Urology 64:7-11

69. Chopra B et al (2005) Expression and function of bradykinin B1 and $\mathrm{B} 2$ receptors in normal and inflamed rat urinary bladder urpthelium. J Physiol 562:859-871

70. Birder LA et al (2004) Alternations in P2X and P2Y purinergic receptor expression in urinary bladder from normal cats and cats with interstitial cystitis. Am J Physiol 287:F1084-F1091

71. Kumar V, Chapple CC, Chess-Williams R (2004) Characteristics of ATP corrected release from procine and human normal bladder. J Urol 172:744-747
72. Scott RS, Uvelius B, Arner A (2004) Changes in intracellular calcium concentration and $\mathrm{P} 2 \mathrm{X} 1$ receptor expression in hypertrophic rat urinary bladder smooth muscle. Neurourol Urodyn 23:361-366

73. Tempest HV et al (2004) P2X receptor expression in human bladder urothelium and changes in interstitial cystitis. BJU Int 93:1344-1348

74. Sun Y, Chai TC (2004) Up-regulation of P2X3 receptor during stretch of bladder urothelial cells from patients with interstitial cystitis. J Urol 171:448-452

75. Wada H, Otomo R, Shimoda N, Sato S, Sato K, Kato T (2003) Acceleration of ATP-induced contraction in the obstructed bladder of the rat. Nippon Hinyokika Gakkai Zasshi 94:439-447

76. Pandita RK, Andersson KE (2002) Intravesical ATP stimulates the micturition reflex in awake, freely moving rats. J Urol 168:1230-1234

77. Sun Y, Chai TC (2002) Effects of dimethyl sulfoxide and heparin on stretch-activated ATP release by bladder urothelial cells from patients with interstitial cystitis. BJU Int 90:381-385

78. Birder LA et al (2002) Altered urinary bladder function in mice lacking the vanilloid receptor TRPV1. Nat Neurosci 5:856-860

79. Vlaskovska M et al (2001) P2X3 knockout mice reveal a major sensory role for urothelialy released ATP. J Neurosci 21:5670-5677

80. Yiangou $\mathrm{Y}$ et al (2001) Capsaicin receptor VR1 and ATP-gated ion channel P2X3 in human urinary bladder. BJU Int 87(9):774 779

81. Dunn PM, Zhong Y, Burnstock G (2001) P2X receptor in peripheral neurons. Prog Neurobiol 65(2):107-134

82. Lecci A (2001) P2X3 receptors and vanilloids in the micturition reflex pathway. Trends Pharmacol Sci 22:11-12

83. Cockayne DA et al (2000) Urinary bladder hyporeflexia and reduced pain-related behaviour in P2X3-deficient mice. Nature 407:1011-1015

84. Smith TM, KIrley TL (1998) Cloning, sequencing, and expression of a human brain ecto-apyrase related to both the ectoATPases and CD39 ecto-apyrases1. Biochim Biophys Acta 1386:65-78

85. Braun N, Fengler S, Ebeling C, Servos J, Zimmerman H (2000) Sequencing, functional expression and characterization of a rat NTPDase6, a nucleoside disphosphate and novel member of the ecto-nucleoside triphosphate diphosphohydrolase family. Biochem J 351:639-647

86. Turner CM, Vonend O, Chan C, Burnstock G, Unwin RJ (2003) The pattern of distribution of selected ATP-sensitive P2 receptor subtypes in normal rat kidney: an immunohistological study. Cells Tissues Organs 175:105-117

87. Eltze M, Ullrich B (1996) Characterization of vascular P2 purinoceptors in the rat isolated perfused kidney. Eur J Pharmacol 306:139-152

88. Bailey MA (2004) Inhibition of bicarbonate reabsorption in the rat proximal tubule by activation of luminal $\mathrm{P} 2 \mathrm{Y} 1$ receptors. Am J Physiol 287:F789-F796

89. Bailey MA et al (2000) Axial distribution and characterization of basolateral P2Y receptors along the rat renal tubule. Kidney Int 58:1893-1901

90. Bailey MA et al (2004) P2Y receptors present in the native and isolated rat glomerulus. Nephron Physiol 96:79-90

91. Unwin RJ, Bailey MA, Burnstock G (2003) Purinergic signaling along the renal tubule: the current state of play. News Physiol Sci $18: 237-241$

92. Dai LJ, Kang HS, Kerstan D, Ritchie G, Quamme GA (2001) ATP inhibits magnesium uptake in MDCT cells via P2X purinoceptors. Am J Physiol 281:F833-F840

93. Xia SL et al (2004) Extracellular ATP-induced calcium signaling in mIMCD-3 cells requires both $\mathrm{P} 2 \mathrm{X}$ and $\mathrm{P} 2 \mathrm{Y}$ purinoceptors. Am J Physiol 287:F204-F214 
94. McCoy DE et al (1999) Nucleotides regulate $\mathrm{NaCl}$ transport in mIMCD-K2 cells via P2X and P2Y purinergic receptors. Am J Physiol 277:F552-F559

95. Wilson PD, Hovater JS, Casey CC, Fortenberry JA, Schwiebert EM (1999) ATP release mechanisms in primary cultures of epithelia derived from the cysts of polycystic kidneys. J Am Soc Neph 10(2):218-229

96. Turner CM, Ramesh B, Srai SK, Burnstock G, Unwin RJ (2004) Altered ATP-sensitive P2 receptor subtype expression in the Han:SPRD cy/+ rat, a model of autosomal dominant polycystic kidney disease. Cells Tissues Organs 178:168-179

97. Vonend $\mathrm{O}$ et al (2004) Glomerular expression of the ATPsensitive $\mathrm{P} 2 \mathrm{X}$ receptor in diabetic and hypertensive rat models. Kidney Int 66:157-166

98. Hillman KA, Burnstock G, Unwin RJ (2005) The P2X7 ATP receptor in the kidney: a matter of life or death? Nephron Exp Nephrol 101:24-30

99. Hillman KA et al (2004) The P2X7 ATP receptor modulates renal cyst development in vitro. Biochem Biophys Res Commun 322:434-439

100. Hillman KA et al (2002) P2X7 receptors are expressed during mouse nephrogenesis and in collecting duct cysts of the $\mathrm{cpk} / \mathrm{cpk}$ mouse. Exp Nephrol 10:34-42

101. Schwiebert EM et al (2002) Autocrine extracellular purinergic signaling in epithelial cells derived from polycystic kidneys. Am J Physiol 282:F763-F775

102. Shirley DG, Bailey MA, Unwin RJ (2005) In vivo stimulation of apical P2 receptors in collecting ducts: evidence for inhibition of sodium reabsorption. Am J Physiol 288:F1243-F1248

103. Leipziger J (2003) Control of epithelial transport via luminal P2 receptors. Am J Physiol 284:F419-F432

104. Lehrmann H, Thomas J, Kim SJ, Jacobi C, Leipziger J (2002) Luminal P2Y2 receptor-mediated inhibition of sodium absorption in isolated perfused mouse CCD. J Am Soc Neph 13:1018

105. Thomas J, Deetjen P, Ko WH, Jacobi C, Leipziger J (2001) P2Y2 receptor-mediated inhibition of amiloride-sensitive short circuit current in M-1 mouse cortical collecting duct cells. J Membr Biol 183:115-124

106. Insel PA et al (2001) P2Y receptors of MDCK cells: epithelial cell regulation by extracellular ncucleotides. Clin Exp Pharmacol Physiol 28:351-354

107. Vitzthum H, Weiss B, Bachleitner W, Kramer BK, Kurtz A (2004) Gene expression of adenosine receptors along the nephron. Kidney Int 65:1180-1190

108. Jackson EK et al (2006) cAMP-adenosine pathway in the proximal tubule. J Pharmacol Exp Ther 317:1219-1229

109. Liang L, Schwiebert EM (2005) Large pore formation uniquely associated with $\mathrm{P} 2 \mathrm{X} 7$ purinergic receptor channels. Focus on Are second messengers crucial for opening the pore associated with P2X7 receptor? Am J Physiol 288:C240-C242

110. Ostrom RS, Gregorian C, Insel PA (2000) Cellular release of and response to ATP as key determinants of the set-point of signal transduction pathways. J Biol Chem 275:11735-11739

111. Burnstock G (1972) Purinergic nerves. Pharmacol Rev 24:509581

112. Burnstock G (2006) Purinergic signaling. Br J Pharmacol 147: S172-S181

113. Burnstock G (2006) Pathophysiology and therapeutic potential of purinergic signaling. Pharmacol Rev 58:58-86

114. Burnstock G (2006) Historical review: ATP as a neurotransmitter. Trends Pharmacol Sci 27:166-176

115. Burnstock G, Campbell G, Satchell D, Smythe A (1970) Evidence that adenosine triphosphate or a related nucleotide is the transmitter substance released by non-adrenergic inhibitory nerves in the gut. Br J Pharmacol 40:668-688
116. Drury AN, Szent-Gyorgyi A (1929) The physiological activity of adenine compounds with specific reference to their action upon the mammalian heart. J Physiol 68:213-237

117. Gordon JL (1986) Extracellular ATP: effect, sources and fates. Biochem J 233:309-319

118. Schwiebert EM, Kishore BK (2001) Extracellular purinergic signaling along the renal epithelium. Am J Physiol Renal Physiol 280:F945-F963

119. Schwiebert EM (2001) ATP release mechanisms, ATP receptors, and purinergic regulation along the nephron. Clin Exp Pharmacol Physiol 28:340-350

120. Schwiebert EM, Liang L, Cheng NL, Olteanu D, Richards Williams C, Welty EA, Zsembery A (2005) Extracellular ATP- and zinc-gated P2X receptor calcium entry channels: physiological sensors and therapeutic targets. Purinergic Signal 1(4):299-310

121. Schwiebert EM, Zsembery A (2003) Extracellular ATP as a signaling molecule for epithelial cells. Biochim Biophys Acta 1615:7-32

122. Turner CM, King BF, Srai KS, Unwin RJ (2006) Antagonism of endogenous putative $\mathrm{P} 2 \mathrm{Y}$ receptors reduced the growth of MDCK-derived cysts cultured in vitro. Am J Physiol Renal Physiol 292(1):F15-F25

123. Wilson PD, Hovater JS, Casey CC, Fortenberry JA, Schwiebert EM (1999) ATP release mechanisms in primary cultures of epithelia derived from the cysts of polycystic kidneys. J Amer Soc Neph 10:218-229

124. Schwiebert EM, Wallace DP, Braunstein GM, King SR, Peti-Peterdi J, Hanaoka K, Guggino WB, Guay-Woodford LM, Bell PD, Sullivan LP, Grantham JJ, Taylor AL (2002) A detrimental autocrine and paracrine purinergic signaling loop exists in epithelial cells derived from polycystic kidneys. Am J Physiol 282:F763F775

125. Abbracchio MP, Burnstock G (1994) Purinoceptors: are there families of P2X and P2Y purinoceptors? Pharmacol Ther $64: 445-475$

126. Braunstein GM, Zsembery A, Tucker TA, Schwiebert EM (2004) Purinergic signaling underlies CFTR control of human airway epithelial cell volume. J Cyst Fibros 3(2):99-117

127. Taylor AL, Kudlow BA, Marrs KL, Gruenert DC, Guggino WB, Schwiebert EM (1998) Bioluminescence detection of ATP release mechanisms in epithelia. Am J Physiol Cell Physiol 275:C1391-C1406

128. Ishikawa S, Higashiyama M, Kusaka I, Saito T, Nagasaka S, Fukuda S (1997) Extracellular ATP promotes cellular growth of renal inner medullary collecting duct cells mediated by P2U receptors. Nephron 76:208-214

129. Knowles MR, Clarke LL, Boucher RC (1991) Activation of extracellular nucleotides of chloride secretion in the airway epithelia of patients with cystic fibrosis. N Eng J Med 325:533538

130. Luo X, Zheng W, Yan M, Lee MG, Muallem S (1999) Multiple functional P2X and P2Y receptors in the luminal and basolateral membranes of pancreatic duct cells. Am J Physiol Cell Physiol 277(2):C205-C215

131. McCoy DE, Taylor AL, Kudlow BA, Karlson KH, Slattery MJ, Schwiebert LM, Schwiebert EM, Stanton BA (1999) Nucleotides regulate $\mathrm{NaCl}$ transport across mIMCD-K2 cells via $\mathrm{P} 2 \mathrm{X}$ and P2Y purinergic receptors. Am J Physiol 277:F552-F559

132. Taylor AL, Schwiebert LM, Smith JJ, King C, Jones JR, Sorscher EJ, Schwiebert EM (1999) Epithelial P2X purinergic receptor channel expression and function. J Clin Invest 104:875884

133. Turner CM, Vonend O, Chan C, Burnstock G, Unwin RJ (2003) The pattern of distribution of selected ATP-sensitive $\mathrm{P} 2$ receptor subtypes in normal rat kidney: an immunohistological study. Cells Tissues Organs 175:105-117 
134. Weisman GA et al (2005) Molecular determinants of P2Y2 nucleotide receptor function: implications for proliferative and inflammatory pathways in astrocytes. Mol Neurobiol 31:169-183

135. Zsembery A, Boyce AT, Liang L, Peti-Peterdi J, Bell PD, Schwiebert EM (2003) Sustained calcium entry through P2X nucleotide receptor channels in human airway epithelial cells. J Biol Chem 278:13398-13408

136. Zsembery A, Fortenberry JA, Liang L, Bebok Z, Tucker TA, Boyce AT, Braunstein GM, Welty EA, Bell PD, Sorscher EJ, Clancy JP, Schwiebert EM (2004) Extracellular zinc and ATP restore chloride secretion across cystic fibrosis airway epithelia by triggering calcium entry. J Biol Chem 279:10720-10729

137. Boese SH, Glanville M, Aziz O, Gray MA, Simmons NL (2000) Calcium and cyclic AMP-activated chloride conductances mediate chloride secretion in a mouse renal inner medullary collecting duct cell line. J Physiol 523:325-338

138. Calvet JP, Grantham JJ (2001) The genetics and physiology of polycystic kidney disease. Semin Nephrol 21(2):107-123

139. Grantham JJ (2001) Polycystic kidney disease: from the bedside to the gene and back. Curr Opin Nephrol Hypertens 10(4):533542

140. Hanaoka K, Devuyst O, Schwiebert EM, Wilson PD, Guggino WB (1996) A role for CFTR in human autosomal dominant polycystic kidney disease. Am J Physiol Cell Physiol 270(1): C389-C399

141. Kizer NL, Lewis B, Stanton BA (1995) Electrogenic sodium absorption and chloride secretion by an inner medullary collecting duct cell line (mIMCD-K2). Am J Physiol Renal Physiol 268:F347-F355

142. Kizer NL, Vandorpe D, Lewis B, Bunting B, Russell J, Stanton BA (1995) Vasopressin and cyclic AMP stimulate electrogenic chloride secretion in an IMCD cell line. Am J Physiol Renal Physiol 268:F854-F861

143. Mangoo-Karim R, Uchic ME, Grant M, Shumate WA, Calvet JP, Park CH, Grantham JJ (1989) Renal epithelial fluid secretion and cyst growth: the role of cyclic AMP. FASEB J 3:2629-2632

144. Mangoo-Karim R, Ye M, Wallace DP, Grantham JJ, Sullivan LP (1995) Anion secretion drive fluid secretion by monolayers of cultured human polycystic kidney cells. Am J Physiol 269:F381F388

145. Simmons NL (1993) Renal epithelial chloride secretion. Exp Physiol 78(2):117-137

146. Simmons NL (1981) Identification of a purine (P2) receptor linked to ion transport in a cultured renal (MDCK) epithelium. Br J Pharmacol 73:379-384

147. Simmons NL (1981) Stimulation of chloride secretion by exogenous ATP in cultured MDCK epithelial monolayers. Biochim Biophys Acta 646:231-242

148. Stewart GS, Glanville M, Aziz O, Simmons NL, Gray MA (2001) Regulation of an outwardly rectifying chloride conductance in renal epithelial cells by external and internal calcium. $\mathrm{J}$ Membr Biol 180(1):49-64

149. Stutts MJ, Fitz JG, Paradiso AM, Boucher RC (1994) Multiple modes of regulation of airway epithelial chloride secretion by extracellular ATP. Am J Physiol 267:C1442-C1451

150. Sullivan LP, Wallace DP, Grantham JJ (1998) Chloride and fluid secretion in polycystic kidney disease. J Am Soc Neph 9(5):903916

151. Sullivan LP, Wallace DP, Grantham JJ (1998) Epithelial transport in polycystic kidney disease. Physiol Rev 78(4):1165-1191

152. Hurley DK, Bandy SM, Glew RH, Morris DM, Gardner KD (1997) Kidney and breast cysts: a comparative study of fluids. Nephron 77:304-308

153. Guay-Woodford LM (2003) Murine models of polycystic kidney disease: molecular and therapeutic insights. Am J Physiol 285: F1034-F1049
154. Guay-Woodford LM, Desmond RA (2003) Autosomal recessive polycystic kidney disease: the clinical experience in North America. Pediatrics 111(5):1072-1080

155. Olteanu D et al (2006) Heightened ENaC-mediated sodium absorption in a murine polycystic kidney disease model epithelium lacking apical monocilia. Am J Physiol 290:C952-C963

156. Amstrup J, Novak I (2003) P2X7 receptor activates extracellular signal-regulated kinases ERK1 and ERK2 independently of calcium influx. Biochem J 374:51-61

157. Morelli A et al (2003) Extracellular ATP causes ROCK-1 dependent bleb formation in P2X7-transfected HEK293 cells. Mol Biol Cell 14:2655-2664

158. Nandigama R, Padmasekar M, Wartenberg M, Sauer H (2006) Feed forward cycle of hypotonic stress-induced ATP release, purinergic receptor activation, and growth stimulation of prostate cancer cells. J Biol Chem 281:5686-5693

159. Edwin F, Wiepz GJ, Singh R, Peet CR, Chaturvedi D, Bertics PJ, Patel TB (2006) A historical perspective of the EGF receptor and related systems. Methods Mol Biol 327:1-24

160. Erb L, Liao Z, Seye CI, Weisman GA (2006) P2 receptors: intracellular signaling. Pflugers Arch 452:552-562

161. Gonzalez-Perret S, Kim K, Ibarra C, Damiano AE, Zotta E, Batelli M, Harris PC, Reisin IL, Arnaout MA, Cantiello HF (2001) Polycystin-2, the protein mutated in autosomal dominant polycystic kidney disease (ADPKD) is a calcium-permeable nonselective cation channel. Proc Natl Acad Sci USA 98(3): $1182-1187$

162. Hanaoka K, Guggino WB (2000) Cyclic AMP regulates cell proliferation and cyst formation in autosomal dominant polycystic kidney disease cells. J Am Soc Neph 11(7):1179-1187

163. Hanaoka K, Qian F, Boletta A, Bhunia AK, Piontek K, Tsiokas L, Sukhatme VP, Guggino WB, Germino GG (2000) Coassembly of polycystin-1 and polycystin-2 produces unique cation-permeable currents. Nature 408(6815):990-994

164. Harris PC (2002) Molecular basis of polycystic kidney disease: PKD1, PKD2, and PKHD1. Curr Opin Nephrol Hypertens 11 (3):309-314

165. Hughes J, Ward CJ, Peral B, Aspinwall R, Clark K, San Millan JL, Gamble V, Harris PC (1995) The polycystic kidney disease 1 (PKD1) gene encodes a novel protein with multiple cell recognition domains. Nat Genet 10(2):151-160

166. Koulen P, Cai Y, Geng L, Maeda Y, Nishimura S, Witzgall R, Ehrlich BE, Somlo S (2002) Polycystin-2 is an intracellular calcium release channel. Nat Cell Biol 4(3):191-197

167. Luo Y, Vassilev PM, Li X, Kawanabe Y, Zhou J (2003) Native polycystin-2 functions as a plasma membrane calcium-permeable cation channel in renal epithelia. Mol Cell Biol 23(7):2600-2607

168. Nauli SM et al (2003) Polycystins 1 and 2 mediate mechanosensation in the primary cilium of kidney cells. Nat Genet 33 (2): $129-137$

169. Newby LJ, Streets AJ, Zhao Y, Harris PC, Ward CJ, Ong AC (2002) Identification, characterization, and localization of a novel kidney polycystin-1/polycystin-2 complex. J Biol Chem 277(23):20763-20773

170. Orellana SA, Sweeney WE, Neff CD, Avner ED (1995) Epidermal growth factor receptor expression is abnormal in murine polycystic kidney. Kidney Int 47:490-499

171. Pazour GJ, Rosenbaum JL (2002) Intraflagellar transport and cilia-dependent diseases. Trends Cell Biol 12(12):551-555

172. Qian F, Germino FJ, Cai Y, Zhang X, Somlo S, Germino GG (1997) PKD1 interacts with PKD2 through a coiled-coil domain. Nat Genet 16(2):179-183

173. Richards WG, Sweeney WE, Yoder BK, Wilkinson JE, Woychik RP, Avner ED (1998) Epidermal growth factor receptor activity mediates renal cyst formation in polycystic kidney disease. J Clin Invest 101:935-939 
174. Sutters M, Germino GG (2003) Autosomal dominant polycystic kidney disease: molecular genetics and pathophysiology. J Lab Clin Med 141(2):91-101

175. Wilson PD (1997) Epithelial cell polarity and disease. Am J Physiol Renal Physiol 272(4):F434-F442

176. Wilson PD (2001) Polycystin: new aspects of structure, function, and regulation. J Am Soc Neph 12(4):834-845

177. Wilson PD (2002) The genes and proteins associated with polycystic kidney diseases. Minerva Urol Nefrol 54(4):201-211

178. Wilson PD, Du J, Norman JT (1993) Autocrine, paracrine and endocrine regulation of growth abnormalities in autosomal dominant polycystic kidney disease. Eur J Cell Biol 61:131-138

179. Wu G, Somlo S (2000) Molecular genetics and mechanism of autosomal dominant polycystic kidney disease. Mol Genet Metab 69(1):1-15
180. Yoder BK, Hou X, Guay-Woodford LM (2002) The polycystic kidney disease proteins polycystin-1, polycystin-2, Polaris, and cystin are co-localized in renal cilia. J Am Soc Nephrol 13 (10):2508-2516

181. Zhang Q, Taulman PD, Yoder BK (2004) Cystic kidney disease: all roads lead to the cilium. Physiology (Bethesda) 19:225-230

182. Doctor RB et al (2006/2007) Regulated ion transport in mouse liver cyst epithelial cells. Biochim Biophys Acta 1772(3):345-354

183. Liu W, Murcia NS, Duan Y, Weinbaum S, Yoder BK, Schwiebert EM, Satlin LM (2004) Mechanoregulation of intracellular $\mathrm{Ca}^{2+}$ concentration is attenuated in collecting duct of monociliumimpaired orpk mice. Am J Physiol Renal Physiol 289:F978-F988

184. Praetorius HA, Frokiaer J, Leipziger J (2005) Transepithelial pressure pulses induce nucleotide release in polarized MDCK cells. Am J Physiol 288:F133-F141 